\title{
Pre- Probiyotikler ve Diyabet
}

\author{
Pre- Probiotics and Diabetes
}

\section{Hülya Kamarlı ${ }^{1}$}

Geliş tarihi/Received: 14.01.2019 • Kabul tarihi/Accepted: 21.04.2019

\section{ÖZET}

Diabetes Mellitus, son 10 yılda prevalansı dünya çapında ciddi artış gösteren bir halk sağlığı sorunudur. Çeşitli nedenlere bağlı olarak ortaya çıkan diyabetin patogenezinde yetersiz fiziksel aktivite ve yanlış beslenme alışkanlıklarını içeren olumsuz yaşam tarzı değişikliklerine bağlı olarak meydana gelen insulin direnci ile genetik faktörlerin önemli rol oynadığı kabul gören yaygın görüşler arasındadır. Ancak son yıllarda çevresel faktörlerin de diyabet patogenezindeki etkisini gösteren kanıtlar ortaya çıkmıştır. Bu faktörlerden en çok üzerinde durulan ise mikrobiyotadır. Yürütülen çalışmalarla da mikrobiyotadaki değişen bakteri dengesinin; bağırsak geçirgenliğinde artışa, kanda Glukagon Benzeri Peptid-1 ve Glukagon Benzeri Peptid2'nin azalmasına ve endotoksin artışına neden olduğu gösterilmiştir. Bu hormonal değişiklikler ve endotoksemi ise hedef organlarda lipogenez, yağ kütlesi, inflamasyon ve makrofaj inflitrasyonunda artış; insülin duyarlılığı, beta hücre kütlesi ve plazma insülin düzeyinde ise azalmaya neden olarak diyabetin ortaya çıkmasına katkıda bulunmaktadır. Diyabetin önüne geçebilmek ya da komplikasyonlarının oluşumunu engelleyebilmek için bağırsak mikrobiyotasında meydana gelen değişikliklerin eski haline getirilmesi ise temel amaçtır. Mikrobiyotayı düzenlemek için esas olan beslenmedir ve son yıllarda yapılan çalışmalarla prebiyotik ve probiyotik müdahaleleri ile bağırsak florasının eski haline getirilebileceği belirtilmektedir. Prebiyotikler ve probiyotiklerin diyabetik hastalarda inflamasyonu azaltmada, kan lipit profilini optimal seviyelerde tutmada, kilo kontrolünü sağlamada, antioksidan savunmayı düzeltmede, insülin duyarlılığını ve pankreas $\beta$-hücre fonksiyonlarını iyileştirerek kan şekeri regülasyonunu sağlamada etkili olduğu gösterilmiştir.

Anahtar kelimeler: Diabetes mellitus, prebiyotik, probiyotik

\section{ABSTRACT}

The prevalence of Diabetes Mellitus has emerged as a public health problem with a worldwide increase in prevalence over the last 10 years. In the pathogenesis of diabetes which occurs due to various causes, it is widely accepted that insulin resistance and genetic factors, which are caused by negative lifestyle changes including physical inactivity and wrong eating habits, play an important role. However, in recent years, evidence has shown that environmental factors also have an effect on the pathogenesis of diabetes. The most important one of these factors is the microbiota. It has been shown in the studies that the changing bacterial balance in the microbiota causes an increase in intestinal permeability, a decrease in Glucagon-Like Peptide-1 and Glucagon-Like Peptide-2 and an increase in endotoxin in the blood. These hormonal changes and endotoxemia contribute to the development of diabetes, leading to an increase in lipogenesis, fat mass, inflammation and macrophage infiltration in target organs, and a decrease in insulin sensitivity, beta cell mass, and plasma insulin level. The main objective is to restore the changes in the intestinal microbiota in order to prevent diabetes or the occurrence of complications. It is the nutrition that is essential to regulate the microbiota, and it is stated that intestinal flora can be

1. İletişim/Correspondence: Akdeniz Üniversitesi, Sağlık Bilimleri Fakültesi, Beslenme ve Diyet Bölümü, Antalya, Türkiye

E-posta: hkamarli@akdeniz.edu.tr • $\odot$ https://orcid.org/0000-0001-9878-9297 
restored with prebiotic and probiotic interventions in the studies carried out in recent years. Prebiotics and probiotics have been shown to be effective in decreasing inflammation in diabetic patients, maintaining the blood lipid profile at optimal levels, providing weight control, correcting antioxidant defense, improving insulin sensitivity and pancreatic $\beta$-cell functions, and providing blood glucose regulation.

Keywords: Diabetes mellitus, prebiotics, probiotics

\section{Gíriş}

Kronik hiperglisemi ile karakterize bir hastalık olan Diabetes Mellitus (DM), son ylllarda prevalansı gün geçtikçe artan önemli bir halk sağlığı sorunudur $(1,2)$. Birçok nedene bağlı olarak ortaya çıkan diyabetin patogenezinde; Batı tipi obezojenik diyet (doymuş ve trans yă̆ asitleri ile basit şekerlerden zengin, posadan fakir) ile fiziksel aktivite azlığı gibi olumsuz yaşam tarzı değişiklikleri, genetik yatkınlık ve epigenetik değişikliklerin de içinde bulunduğu risk faktörlerine bağlı olarak oluşan inflamasyon, dislipidemi, inkretin hormonlarının sekresyonundaki bozukluklar, endotoksemi, adipozite, oksidatif stres, $\beta$-hücre disfonksiyonuna bağlı olarak gelişen hiperglisemi ve insülin direnci rol almaktadır (3). Son yıllarda tüm bu nedenlerin yanı sira diyabet ve obezite gibi birçok metabolik temelli hastalıkların oluşumunda kommensal bakteri, virüs ve kimyasallar gibi çevresel faktörlerin de etkisinin olabileceği ileri sürülmüş ve bu konuya açıklı getirmek için çalışmalar yapılmaya başlanmıştır. Bu faktörlerden bağırsak mikroflorasındaki değişikliklerin ve bozulmuş bağırsak bariyerinin diyabet oluşumunda önemli bir yere sahip olduğu gösterilmiştir (3-5). Bu derleme yazının amacı diyabetin önlenmesinde ve yönetiminde pre-probiyotiklerin rolü ve etkisinin irdelenmesidir.

\section{Bağırsak Mikrobiyotası}

Bağırsak mikroflorasının yapısı, oranı ve bileşimindeki bozukluklar bireylerin sağlık durumunun olumsuz etkilenmesine ve insan vücudundaki çeşitli süreçlerin değişmesine neden olmaktadır. Diyet, antibiyotikler ve radyasyon gibi çeşitli faktörlere bağlı olarak intestinal sistemin dengesinde meydana gelen bu bozukluklar bağırsak mikrobiyotasının bileşiminde bulunan yararlı ve zararlı bakterilerinin dengesinin değişmesi sonucunda ortaya çıkmaktadır $(3,6,7)$. Böyle bir durumda bağırsak mikrobiyotasını eski haline getirmek suretiyle ortaya çıkan bu olumsuzlukların ve hastalıkların ciddiyetinin azalması sağlanabilmektedir.

Bağırsak mikrobiyotası yaklaşık $10^{14}$ mikroorganizmanın yaşadığı, çoğunluğu farklı bakteri türleri ve suşlarından oluşmuş, azınlık olarak da virüsler, mantar ve ökaryotik hücrelerin bulunduğu bir ekosistemdir (3,8,9). Mikrobiyotadaki bakterilerin çoğunluğunu gram pozitif Firmicutes (\%60-80; Ruminococcus, Clostridium ve Lactobacillus) ile gram negatif Bacteroidetes (\%20-30; Bacteroides, Prevotella ve Xylanibacter) oluşturmaktadır. Azınlık kısmını ise gram pozitif Actinobacteria ile gram negatif Escherichia ve Enterobacteriaceae gibi Proteobacteria meydana getirmektedir (6,9). Gastrointestinal sistem mikrobiyotasına bakıldığında bakterilerin çoğunluğunun ileum ve kolonda yerleşmiş olduğu, kolondaki bakteri kolonizasyonunun büyük kısmını da probiyotik bakterilerin oluşturduğu görülmektedir (8). Doymuş ve çoklu doymamış yağ asitleri gibi besin ögelerinin aşırı alınması veya oligosakkaritler ve fitokimyasalların eksik alınması gibi yanlış beslenme uygulamaları bakteriyel metabolik aktiviteyi değiştirerek, konakçı mikrobiyotası için yararlı olan Bifidobacterium sayısının azalmasına, Firmicutes sayısının ise yükselmesine neden olmaktadır. Ayrıca yüksek yağ içeren diyetler bağırsak geçirgenliğini artırmak ve mikrobiyal antijenlere duyarlılığı değiştirmek suretiyle bağırsak bakterilerinin translokasyonuna izin vermekte ve artan bakteri kolonizasyonu da insülin direncini artırarak diyabete yol açmaktadır. Diyabetik bireylerin mikrobiyotası 
incelendiğinde ise bütirat üretimini sağlayan bakterilerde (Roseburia intestinalis ile F. Prausnitzii) azalma; Lactobacillus gasseri, Streptococcus muatans, Escherichia (E. rectale) ve bazı Clostridium türlerinin artış olduğu görülmüştür. Roseburia, Eubacterium hali ve Faecalibacterium prauznitzii insulin direncini azaltırken; L. gasseri, S. mutans ve E. coli insulin direncini arttırarak diyabete yol açmaktadır $(6,9,10)$.

Bağırsak mikrobiyotasının bakteri kolonizasyonunda yaş, etnik yapı, beslenme alışkanlıkları, antibiyotikler, radyasyon, prebiyotikler ve probiyotikleri gibi çeşitli faktörlere bağlı olarak meydana gelen değişim; bağırsak geçirgenliğinde artış, Glukagon benzeri peptid-1 (Glucagon like peptid-1 [GLP-1]) ve GLP2 gibi inkretin hormonlarınin sekresyonunun baskılanması ve insülin sinyalizasyonunun inhibe olmasına neden olmaktadır (7,11). Ayrıca mikrobiyota bakteri kompozisyonundaki değişiklikler infeksiyon, immün bozukluklar, inflamasyon, oksidatif stres ve insülin direncine duyarlılığı artırmaktadır. Bu olaylara, zararlı bağırsak ürünlerine özellikle de gram negatif bakteri hücre duvarının bir bileşeni olan lipopolisakkarite maruz kalmayı da içeren metabolik endotoksemi aracılık etmektedir. Lipopolisakkarit (LPS) endotel hücreler, monositler ve makrofajlar üzerinden toll benzeri reseptör-4'e (TLR-4) bağlanarak; nükleer faktör kappa B (NF-kB) ve aktivatör protein-1 aktivasyonu ile inflamatuar yanıt ve oksidatif stresi başlatmaktadır. Metabolik endotoksemi de lipogenez, inflamasyon ve makrofaj infiltrasyonunda artış ile endotel hücre hasarı ve işlev bozukluklarına yol açarak; insülin duyarlılığı, $\beta$-hücre kütlesi ve plazma insülin düzeylerinde azalmaya sebep olarak, metabolik hastalıkların ve özellikle diyabetin oluşumuna katkıda bulunmaktadır $(12,13)$.

Konakçı metabolizmasını iyileştirmek için metabolik hastalıklara neden olan bağırsak mikrobiyotasını dışarıdan yapılacak müdahalelerle değiştirmek ve eski haline getirmek son yıllarda oldukça ilgi görmeye başlamış bir görüştür. Bağırsak mikrobiyotasındaki değişiklikler birçok faktöre bağlı olarak oluşsa da mikrobiyotanın düzenlenmesi için esas olan sağlıklı ve doğru beslenmedir. $\mathrm{Bu}$ nedenle mikrobiyotayı düzenlemek adına probiyotik kullanımı ile bağırsaklarda probiyotik bakteri sayısını, etkinliğini ve aktivitesini artıran prebiyotiklere olan ilgi son zamanlarda artmaya başlamış ve bunlarla ilgili yapılan çalışma sayıları da artış göstermiştir $(8,10,14)$.

\section{Probiyotikler ve Diyabet}

Probiyotikler "yeterli miktarda alındığında konağın bağırsaklarında mikrobiyal dengeyi düzenleyerek, sağlığını olumlu yönde etkileyen canlı mikroorganizmalardır" olarak tanımlanmaktadır (15).

Bir mikroorganizmanın probiyotik olarak kabul edilebilmesi için vücutta belirli fonksiyonları yerine getirebilmesi ve bazı özellikleri taşıması gerekmektedir. Bir mikroorganizmanın probiyotik olarak kabul görmesi için; yüksek sayıda mikroorganizma içermesi, patojen ve toksiközelliklere sahip olmaması, besin katkı maddeleri ile işleme koşullarına dirençli olması, saklama ve kullanım sırasında da besinlerde canlılığını sürdürebilmesi gerekmektedir. Ayrıca mide asidi, safra ve pankreatik salgılara karşı dirençli olmalı, bağırsaklarda canlılığını ve vücutta metabolik aktivitesini devam ettirebilmeli, bağırsak epiteline tutunarak, gastrointestinal sisteme kolonize olabilmeli ve antimikrobiyal özellikte maddeler salgilayarak, patojen bakterilerin konağa tutunmasını inhibe edebilmelidir $(16,17)$. Konakta bu özellikleri sağlayan probiyotik mikroorganizmalar Lactobacillus ve Bifidobacterium gram pozitif bakteri suşları ile probiyotik özelliği kanıtlanmış bir maya olan Saccharomyces cerevisiae Boulardii'dir (18).

Probiyotiklerin hastalıklar üzerindeki etkinliklerinin araştırıldığı çalışmalarda probiyotiklerin; diyabet ve pek çok hastalık üzerine etkilerinin olduğu gözlemlenmiştir (3). Her hastalıkta farklı etki mekanizmaları olmasına rağmen genel olarak probiyotik mikroorganizmalar hastalıklardaki etkinliklerini; besinlerin biyoyararlılığını artırarak, bağırsak epitel reseptörleri için patojenlerle yarışarak, müsin sekresyonunu artırmak yoluyla probiyotiklerin bağırsak mukozasına bağlanmasını sağlarken patojenlerin ve toksinlerin bağlanmasını 
engelleyerek, bağırsak bariyerinin güçlendirilmesi ve stabile edilmesiyle doğal bağışıklık yanıtını uyararak inflamasyonu azaltmak yoluyla yapmaktadır. Ayrica laktik asit, asetik asit ve propiyonik asit gibi organik asitler, hidrojen peroksit, serbest yağ asitleri ve bakteriyosinleri de içeren patojen mikroorganizmalarla savaşan yararlı antimikrobiyal bileşikleri açı̆̆a çıkararak, bazı interferonları ve interlökinleri uyararak, sitokin profillerini değiştirerek konakçının immün sisteminin uyarılması ve geliştirilmesiyle mikrobiyotayı düzenler ve bağırsak sağlığını iyileştirir $(11,19)$. Vücuttaki bu etkileriyle probiyotikler organizmadaki patojen kolonizasyonları inhibe ederek, bağırsak mikrobiyota popülasyonlarının modülasyonu ve çeşitliliğini sağlayarak; yağ kütlesi birikimi ve kolesterolü, bağırsak geçirgenliğini, metabolik endotoksemiyi ve proinflamatuvar sitokinleri azaltırken, antiinflamatuvar sitokinleri, glukoz toleransı ile insülin duyarlılığını da artırmaktadır (4).

Sağlıklı bireylere kıyasla diyabetiklerin bağırsak mikrobiyotalarının kompozisyonunda Firmicutes daha düşük iken, Bacteroidetes ve Proteobacteria oranları daha yüksektir. Diyabetik mikrobiyomda ayrıca Clostridia ve Escherichia oranları da anlamlı olarak artmıştır. Anti-inflamatuvar özelliklere sahip olan gram pozitif bakterilerden Bifidobacterium ve Faecalibacterium prausnitzii sayıları da azalmıştır $(6,10)$.

Mikrobiyotada gram negatif bakteri popülasyonunun çoğalması ile inflamasyon arasında da ilişki olduğu belirtilmiştir. Gram negatif bakterilerin aşırı artması LPS maruziyetinin artması ile endotoksemi ve insülin direncine neden olmaktadır. Ayrıca enterositlerin yüzeyinde bulunan TLR'ler NF-kB yolağını aktive ederek inflamasyonu başlatmaktadır. İnflamasyon sonucunda da yine diyabetin patogenezinde önemli rolü olan insülin direnci ortaya çıkmaktadır (20). Metabolik hastalıklara neden olan tüm bu olumsuz etkilerin ortadan kaldırılmasında, diyabetin geciktirilmesi ve önlenmesinde mikrobiyota düzenleyicisi olarak görülen probiyotiklerin yeni bir tedavi stratejisi olarak kullanımı gündeme gelmiştir.
$\mathrm{Bu}$ sebeple de son yıllarda probiyotiklerin diyabet üzerindeki etkinliklerini belirlemek amacıyla birçok hayvan ve insan çalışmaları yürütülmüştür. Yapılan rat çalışmalarında; probiyotik suşu olarak verilen $L$. plantarum ve L. gasseri BNR 17'nin kan glukoz seviyelerini düşürdüğü ve glukoz toleransını düzelttiği, L. acidophilus ve $L$. casei'nin glukoz intoleransı, hiperglisemi, hiperinsülinemi, dislipidemi ve oksidatif stresin ilerlemesini anlamlı olarak geciktirdiği belirtilmiştir. Ayrıca L. casei’nin HbA1c, total kolesterol, trigliserit, çok düşük dansiteli lipoprotein (very low density lipoprotein [VLDL]), düşük dansiteli lipoprotein (low density lipoprotein [LDL]) ve serbest yağ asidi düzeylerini düşürdüğü ve otoimmün diyabetin tetiklenmesinde önemli faktörler olan sitokinler ve $\beta$-hücrelerinin spesifik $\mathrm{CD} 4+\mathrm{T}$ hücrelerinin üretimini inhibe ettiği, proinflamatuar sitokinler interlökin-6 (IL-6) ile C reaktif protein (CRP) seviyelerini düşürdüğü rapor edilmiştir. $L$. casei Shirota türünün ise IL-6 ve CRP'nin kandaki seviyelerini ve diyabetik komplikasyon riskini azalttığı gösterilmiştir. Beslenmesine L. rhamnosus GG eklenen ratlarda ise glukoz toleransının iyileştiği görülmüştür (6,21-23).

L. acidophilus ve $B$. lactis suşlarının diyabetteki etkilerinin incelendiği çalışmalarda, bu suşların hastalarda açlık kan glukozu, fruktozamin, HbA1c, TNF-a, serum IL-6, CRP, resistin, malondialdehit, LDL ve total kolesterol seviyelerinde azalma sağladiğı görülmüştür. Öte yandan yüksek dansiteli lipoprotein (high density lipoprotein [HDL]) kolesterol, eritrosit süperoksit dismutaz, glutatyon peroksidaz aktivitesi ve total antioksidan kapasitesini artirarak hem antidiyabetik hem de anti-inflamatuvar etki gösterdiği saptanmıştır (24-27). L. acidophilus, L. bulgaricus, L. bifidum, L. casei içeren probiyotik kapsül kullanımı diyabetik bireylerde insülin, malondialdehit ve IL-6 seviyesinde azalmaya neden olurken; Bifidobacterium bifidum, B. lactis, L. acidophilus, L. brevis, L. casei, L. salivarius, Lactococcus lactis insülin direncinde ve HbA1c düzeyinde düzelme ile açlık insülin düzeyinde azalmaya yol açmıştır (28-30). S. thermophilus, $L$. casei, L. acidophilus ve B. lactis suşlarını içeren kefir 
tüketiminin ise serum glukoz seviyeleri ile HbA1c'de azalmaya yol açtığı gözlemlenmiştir (31). Probiyotik özelliği olan tek maya Saccharomyces cerevisiae'nın da diyabetiklerde açlık kan glukozu ile HbA1c'de azalma ve insülin duyarlılığında artış sağlayarak, kan şekeri regülasyonunda etkili olduğu belirtilmiştir (32).

Yürütülen çalışma sonuçlarından elde edilen bilgiler doğrultusunda diyabette probiyotik kullanımının hem bifidobakterilerin sayısını artırdığı hem de intestinal geçirgenliğin azalmasını sağlayan adezyon proteinlerinin ekspresyonunu artırdığı gösterilmiştir (10). Ayrıca LPS aracılığıyla TLR-4' ün aktivasyonunu zayıflatmakta, gram negatif bakterilerin translokasyon ve mukozal yapışkanlığını azaltarak ve bağırsaklarda sekretuar immünoglobulin A üretimini teşvik ederek IL-8 ve NF-kB'nin aktivasyon yolaklarını bloke etmek ve inflamatuvar belirteçleri azaltmak suretiyle antiinflamatuvar etki göstermektedir. CD8+ T hücrelerinin pankreatik infiltrasyonunu önlemekte dolayısıyla pankreatik $\beta$-hücre yıkımını engellemektedir (Şekil 1) $(7,10,12,33)$. L. caseii proinflamatuvar molekülleri azaltmak suretiyle oksidatif stresi azaltmakta ve CD4+ Thücrelerinin etkileyici fonksiyonlarını baskılamakta, böylece antioksidan ve bağışıklık düzenleyici etkiler göstermektedir. Ayrıca lipit peroksidasyonu ve nitrik oksit oluşumunu inhibe ederek pankreatik dokularda oksidatif hasarı baskılamaktadır. Probiyotikler diyabetteki bu etki mekanizmaları sonucunda insülin direncini azaltıp, insülin duyarlılığını arttırarak kan glukozu regülasyonunu sağlamakta ve inflamasyon önlenebilmektedir $(6,10)$.

\section{Prebiyotikler ve Diyabet}

Bağırsak mikrobiyotasını düzenlemenin bir yolu bağırsak sağlı̆̆ için yararlı ve koruyucu olan mikroorganizmaları yani probiyotikleri vermek olabileceği gibi diğer bir yolda bağırsaklarda yararlı bakterilerin sayısını ve hayatta kalma sürelerini artırmaya yarayan prebiyotiklerin kullanılmasıdır. Prebiyotikler, gastrointestinal sistemdeki (GIS) bir veya sınırlı sayıdaki bakterinin gelişimini ve/ veya aktivitesini seçici olarak uyarmak yoluyla mikroorganizmaların kompozisyon ve/veya aktivitesini etkileyerek konağın iyi olma hali ve sağlığı üzerinde olumlu etkiler sağlayan sindirilemeyen ve fermente olabilen besin bileşenleri olarak

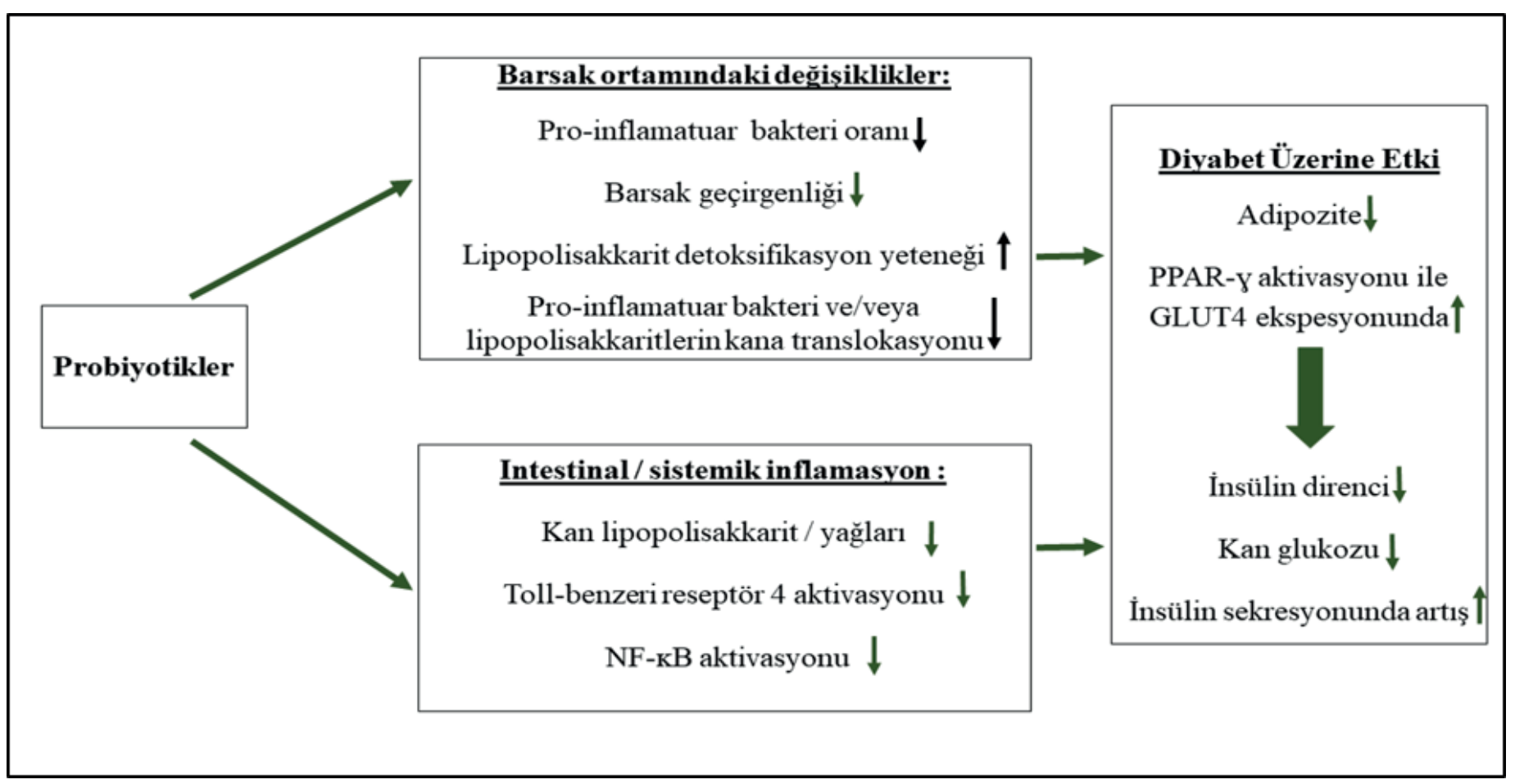

Şekil 1. Diyabette probiyotiklerin etki mekanizması (33). PPAR-8: Perokizom proliferatör-aktive reseptör-8, GLUT4: Glukoz taşıyıcı protein-4, NF-kB: Nüklear faktör kB. 
tanımlanmaktadır (15,34). İşlevsel besin bileşeni olarak kabul edilen prebiyotiklerin en yaygin olarak kullanılanları fruktooligosakkaritler (FOS; oligofruktoz ve inulin), galaktooligosakkaritler (GOSlaktuloz), soya oligosakkaritleri ile dirençli nişastadır $(8,12)$. Bir besin bileşeninin prebiyotik olarak kabul edilebilmesi için üst GIS'de hidrolize olmaması ve emilmemesi, mide asidi ile GIS'deki diğer enzimlere de dirençli olması gerekmektedir. Kolonda bazı bakteriler tarafindan fermente edilebilmeli, kolondaki yararlı bakterilerin metabolizmasını ve büyümesini iyileştirmeli, konağın bağırsak florasını ve lümenini sağlıklı bireylerinkine benzer hale getirebilmeli ve genel sağlık durumunu olumlu yönde etkileyebilmelidir $(8,12,35)$.

Her diyet lifinin prebiyotik özelliği olmasa da prebiyotikler aslında birer diyet lifidir ve fermente edilebilenleri bağırsak florasının kompozisyonunu değiştirerek sağlığı olumlu yönde etkilemektedir (35). Diyabetik bireylerin tıbbi beslenme tedavilerinde glisemik indekslerinin düşük olması nedeniyle tam tahıllı ürünlerin ve kurubaklagillerin tüketimine önem verilmektedir. Yapılan çalışmalarda bu besinlerin yapısında bulunan prebiyotik bileşiklerinin $\beta$-hücre fonksiyonunu iyileştirmek suretiyle insülin sekresyonunu artırdığı, insülin direncini azalttığı ve kan glukoz homeostazını sağladığı gösterilmiştir (36).

Prebiyotik birer lif olan inulin Bifidobacteria ve Lactabacillus gibi yararlı bakterilerin aktivitesini ve büyümesini seçici olarak uyararak bağırsak mikrobiyotasını düzenlemektedir. Sindirilemeyen oligosakkaritler kolondaki anaerob bakteriler aracılığıyla bütirat, propiyonat ve asetat gibi kısa zincirli yă asitlerine (KZYA) fermente olmaktadır. Metabolize olan KZYA'lar vücutta bağırsaklardan emilmekte ve özellikle bütirat kolonositler için hem enerji kaynağı olmakta hem de kolonositlerin proliferasyonu ile farklılaşmasını sağlamakta ve bağırsak geçirgenliğini de azaltmaktadır $(9,11,12,36)$. KZYA'nınözellikledebütiratındiyabetinpatogenezinde önemli fonksiyonları vardır. Yapılan çalışmalarda diyabetik bireylerde mikrobiyota kompozisyonunu olumlu yönde etkileyen KZYA'ların özellikle de bütiratın üretimini sağlayan bakterilerin, $C$. coccoides ve Eubacterium rectale grupları sayısının daha düşük olduğu saptanmıştır. Bütirat pankreasta $\beta$-hücre farklılaşmasını, poliferasyonu ve işlevlerini olumlu yönde iyileştirmekte; insülinin transkripsiyonu ve translasyonunu arttırmakta, $\beta$-hücre apaptozunu önlemekte, karaciğerde glukoneogenezi ve glikojenolizi inhibe ederek etkin bir glisemik kontrolün sağlanmasına katkıda bulunmaktadır (37,38). KZYA'lar, bağırsaklardaki enteroendokrin L hücreleri tarafindan sentezlenen, insülin sekresyonunun artışını uyaran ve insülin duyarlılığını arttıran GLP-1 hormonunun salınıminı arttırmaktadır. GLP1 tokluğu artırmak ve gastrik boşalma zamanını uzatmak suretiyle total enerji alımını azaltarak vücut ağırlık kaybını sağlamakta, glukagon sentezini inhibe etmekte, hepatik glukoneogenezi azaltarak, insülin duyarlılığını artırmaktadır. Ayrıca bağırsak glukoz taşınmasını uyaran ve bağırsak geçirgenliğini azaltan bir proglukagon türevi peptid olan GLP-2'nin üretimini de arttırarak diyabette glukoz toleransını iyileştirmektedir $(11,12,14)$. KZYA'lardan bütirat ayrica proinflamatuvar sitokinlere ve NF-кB'ye yanıt veren genleri dolayısıyla proinflamatuvar sitokinleri azaltmakta; IL-10'u artırmakta ve insülin direnci, oksidatif stres ve inflamasyonda azalmaya yol açmaktadır. Prebiyotiklerin diyabetteki etki mekanizmaları Şekil 2'de özetlenmiştir (36).

Diyabette prebiyotiklerin etkinliklerini araştırmak için yapılan çalışmalarda genellikle inulin, psyllium, dirençli nişasta ve oligofruktoz kullanılmıştır. Oligofruktozun diyabetik ratlarda yağ kütlesi gelişimi, oksidatif stres ve düşük dereceli inflamasyonu azalttığı, bağırsak proglukagon mRNA ekspresyonunu ve plazma GLP-1 seviyelerini arttırarak, glukoz toleransını düzelttiği görülmüştür (39). İnulin ile yapılan çalışmalarda inulin açlık kan glukozu, HbA1c, açlık insülini, insülin direnci, serum IL-4, IL-12, IL-6, interferon- $\gamma$, CRP, TNF-a, plazma LPS düzeylerinde azalma ile IL-10'da anlamlı olmayan yükselme sağlayarak, diyabetik bireylerde metabolik endotoksemi ve inflamasyonu hafifleştirmiş, glisemik kontrol ve serum lipit düzeylerinde iyileşme 


\section{PREBIYYOTIKLER}

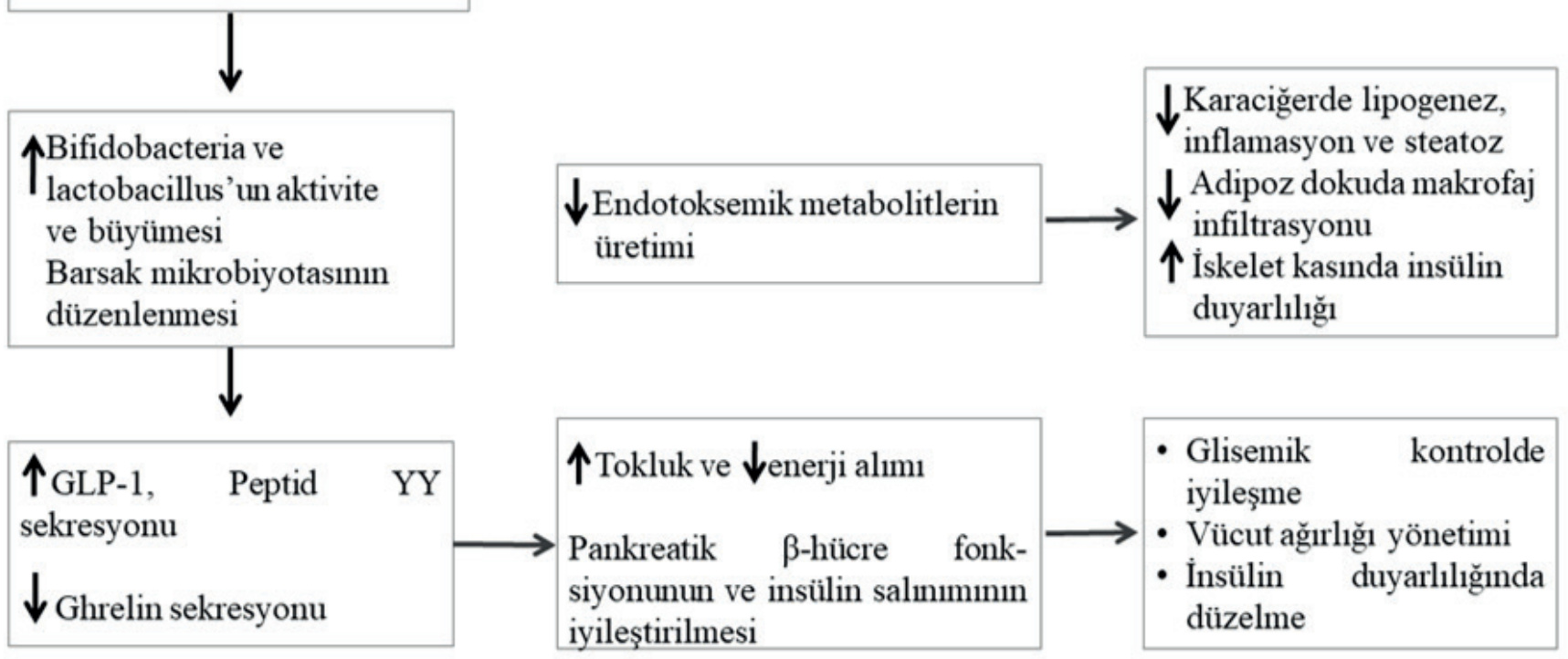

Şekil 2. Diyabette prebiyotiklerin etki mekanizması (36).

sağlamıştır (40,41). Dirençli nişasta ve dekstrin kullanımının ise açlık insülini, insülin direnci, insülin duyarlılık kontrol indeksi, HbA1c, açlık kan glukozu, CRP, TNF- $\alpha$, IL-6, total kolesterol, LDL kolesterol, trigliserit, malondialdehit ve endotoksin konsantrasyonlarinda azalma ve HDL kolesterolde artışa neden olduğu belirtilmiştir $(42,43)$. Psyllium ile yürütülen çalışmalarda da açlık kan glukozu, postprandiyal plazma glukozu ve HbA1c'de azalma, HDL kolesterolde artma ve buna bağlı olarak LDL/HDL kolesterol oranında azalma sağladığı gözlemlenmiştir (44-46).

Hem prebiyotiklerin hem de probiyotiklerin sinbiyotik olarak beraber diyabet üzerindeki etkinliklerinin araştırıldığı çalışmalarda da benzer şekilde açlık kan glukozu, serum insülini, insülin direnç skoru, total kolesterol, VLDL/HDL kolesterol oranı, trigliserit ile inflamasyon belirteçleri olan CRP, IL-6 ve TNF-a düzeylerinde azalma saptanmıştır. Kantitatif insülin duyarlılığı kontrol indeksi, HDL kolesterol, plazma total glutatyon, malondialdehit ve serum ürik asidinde ise artış olduğu gözlemlenmiştir (47-50).

\section{SONUÇ VE ÖNERİLER}

Beslenme alışkanlıklarındaki değişiklikler, fiziksel aktivite yetersizliği, stres, genetik yatkınlık ve immünite bozuklukları bağırsak mikrobiyotasının bileşiminin, yapısının ve mikrobiyotadaki bakteri oranlarının değişmesine neden olarak diyabet gibi birçok metabolik hastalıkların oluşumuna zemin hazırlamaktadır. Mikrobiyotanin bu hastalıkların patogenezindeki yerinin anlaşılmasını takiben, bu hastalıklardan korunmada ve tedavilerinde bağırsak mikrobiyota bileşimini eski haline getirmek için prebiyotik ve probiyotik kullanımı başta olmak üzere mikrobiyota hedefli ajanların kullanımı gündeme gelmiştir. Yapılan çalışmalarda prebiyotik ve probiyotiklerin bağırsak mikrobiyotasını olumlu yönde değiştirdiği, dış kaynaklı hastalıkları ve inflamasyonu azalttığı, diyabetiklerde antioksidan savunmayı düzelttiği, karbonhidrat metabolizması ile inkretin hormonlarının salınımını düzenlediği ve insülin direncini azalttığı gözlemlenmiştir. Ayrıca total enerji alımını azaltarak ve gastrik boşalma zamanını uzatarak vücut ağırlık kaybını sağlamada, pankreatik $\beta$-hücre fonksiyonunu iyileştirerek ve 
insülin sekresyonunu artırarak da açlık kan glukozu ile postprandiyal kan glukozunu düşürmede, kan şekeri regülasyonunu ve optimal lipit profilini sağlamada etkili olduğu görülmüştür.

Dolayısıyla diyabet gibi kronik hastalıkların oluşumunu engellemede ve yönetimini sağlamada etkili bir beslenme stratejisi olarak doğal prebiyotik ve probiyotiklere yer verilmesi, doğal besinlerle yeteri kadar alınamadığında ve gerekli görüldüğü durumlarda ise sağllk profesyonellerinin önerisi ve gözetiminde yapay prebiyotik ve probiyotiklerin kullanılmasının faydalı etkiler gösterebileceği düşünülmektedir.

Çıkar çatışması - Conflict of interest: Yazarlar çılkar çatışması olmadığını beyan ederler. - The authors declare that they have no conflict of interest.

\section{KAYNAKLAR}

1. Bennett PH, Knowler, WC. Definition, diagnosis, and classification of diabetes mellitus and glucose homeostasis. In: Kahn CR, King GL, Moses AC, Weir GC, Jacobson AM and Smith RJ, editors. Joslin's Diabetes Mellitus. 14th ed. New Delhi: Walter Kluwer Pvt. Ltd.; 2010.p:331-339.

2. Türkiye Diyabet Programı 2015-2020. Ankara: TC. Sağlık Bakanlığı, Turkiye Halk Sağlığı Kurumu 2014.

3. Panwar H, Rashmi HM, Batish VK, Grover S. Probiotics as potential biotherapeutics in the management of type 2 diabetes - prospects and perspectives. Diabetes Metab Res Rev. 2013;29(2):103-12.

4. Le Barz M, Anhe FF, Varin TV, Desjardins Y, Levy E, Roy D, et al. Probiotics as complementary treatment for metabolic disorders. Diabetes Metab J. 2015;39(4):291303.

5. Tai N, Wong FS, Wen L. The role of gut microbiota in the development of type 1, type 2 diabetes mellitus and obesity. Rev Endocr Metab Disord. 2015;16(1):55-65.

6. Naydenov K, Anastasov A, Avramova M, Mindov I, Tacheva T, Tolekova A, et al. Probiotics and Diabetes Mellitus. Trakia Journal of Sciences. 2012;10(1):300-6.

7. Mizock BA. Probiotics. Dis Mon. 2015;61(7):259-90.

8. Coşkun T. Probiyotikler/Prebiyotikler. Kara A, Çoşkun T, editör. Teoriden Kliniğe Prebiyotikler Probiyotikler. İstanbul: Akademi Yayınevi; 2014.s. 56-71

9. Munoz-Garach A, Diaz-Perdigones C, Tinahones FJ. Gut microbiota and type 2 diabetes mellitus. Endocrinol
Nutr. 2016;63(10):560-8.

10. Gomes AC, Bueno AA, de Souza RG, Mota JF. Gut microbiota, probiotics and diabetes. Nutr J. 2014;13:60.

11. Shane-McWhorter L. Dietary supplements and probiotics for diabetes. Am J Nurs. 2012;112(7):47-53.

12. Yoo JY, Kim SS. Probiotics and Prebiotics: Present status and future perspectives on metabolic disorders. Nutrients. 2016;8(3):173.

13. Marik PE. Colonic flora, probiotics, obesity and diabetes. Front Endocrinol (Lausanne). 2012;3:87.

14. Idzior-Walus B, Walus-Miarka M. Is now the time for probiotics in diabetes management? Pol Arch Med Wewn. 2015;125(11):797-8.

15. Probiotics and prebiotics. World Gastroenterology Organisation Global Guidelines. February 2017. Avaiable at: http:// www.worldgastroenterology.org/guidelines/ global-guidelines/probiotics-and-prebiotics/probioticsand-prebiotics-english Accessed September 5, 2018.

16. Upadhyay N, Moudgal V. Probiotics: a review. J Clin Outcomes Manage. 2012;19(2):76-84.

17. Williams NT. Probiotics. Am J Health Syst Pharm. 2010;67(6):449-58.

18. Huys G, Botteldoorn N, Delvigne F, De Vuyst L, Heyndrickx M, Pot B, et al. Microbial characterization of probiotics--advisory report of the Working Group "8651 Probiotics" of the Belgian Superior Health Council (SHC). Mol Nutr Food Res. 2013;57(8):1479-504.

19. Nagpal R, Kumar A, Kumar M, Behare PV, Jain S, Yadav H. Probiotics, their health benefits and applications for developing healthier foods: a review. FEMS Microbiol Lett. 2012;334(1):1-15.

20. Lee JY, Hwang DH. The modulation of inflammatory gene expression by lipids: mediation through Toll-like receptors. Mol Cells. 2006;21(2):174-85.

21. Yadav H, Jain S, Sinha PR. Antidiabetic effect of probiotic dahi containing Lactobacillus acidophilus and Lactobacillus casei in high fructose fed rats. Nutrition. 2007;23(1):62-8.

22. Yun SI, Park HO, Kang JH. Effect of Lactobacillus gasseri BNR17 on blood glucose levels and body weight in a mouse model of type 2 diabetes. J Appl Microbiol. 2009;107(5):1681-6.

23. Tabuchi M, Ozaki M, Tamura A, Yamada N, Ishida T, Hosoda M, et al. Antidiabetic effect of Lactobacillus GG in streptozotocin-induced diabetic rats. Biosci Biotechnol Biochem. 2003;67(6):1421-4.

24. Ejtahed HS, Mohtadi-Nia J, Homayouni-Rad A, Niafar M, Asghari-Jafarabadi M, Mofid V. Probiotic yogurt improves antioxidant status in type 2 diabetic patients. Nutrition. 2012;28(5):539-43. 
25. Mohamadshahi M, Veissi M, Haidari F, Javid AZ, Mohammadi F, Shirbeigi E. Effects of probiotic yogurt consumption on lipid profile in type 2 diabetic patients: A randomized controlled clinical trial. J Res Med Sci. 2014;19(6):531-6.

26. Mohamadshahi M, Veissi M, Haidari F, Shahbazian $H$, Kaydani GA, Mohammadi F. Effects of probiotic yogurt consumption on inflammatory biomarkers in patients with type 2 diabetes. Bioimpacts. 2014;4(2):83-8.

27. Tonucci LB, Olbrich Dos Santos KM, Licursi de Oliveira L, Rocha Ribeiro SM, Duarte Martino HS. Clinical application of probiotics in type 2 diabetes mellitus: A randomized, double-blind, placebo-controlled study. Clin Nutr. 2017;36(1):85-92.

28. Mazloom Z, Yousefinejad A, Dabbaghmanesh MH. Effect of probiotics on lipid profile, glycemic control, insulin action, oxidative stress, and inflammatory markers in patients with type 2 diabetes: a clinical trial. Iran J Med Sci. 2013;38(1):38-43.

29. Firouzi S, Majid HA, Ismail A, Kamaruddin NA, Barakatun-Nisak MY. Effect of multi-strain probiotics (multi-strain microbial cell preparation) on glycemic control and other diabetes-related outcomes in people with type 2 diabetes: a randomized controlled trial. Eur J Nutr. 2017;56(4):1535-50.

30. Sabico S, Al-Mashharawi A, Al-Daghri NM, Yakout S, Alnaami AM, Alokail MS, et al. Effects of a multi-strain probiotic supplement for 12 weeks in circulating endotoxin levels and cardiometabolic profiles of medication naive T2DM patients: a randomized clinical trial. J Transl Med. 2017;15(1):249.

31. Ostadrahimi A, Taghizadeh A, Mobasseri M, Farrin N, Payahoo L, Beyramalipoor Gheshlaghi Z, et al. Effect of probiotic fermented milk (kefir) on glycemic control and lipid profile in type 2 diabetic patients: a randomized double-blind placebo-controlled clinical trial. Iran J Public Health. 2015;44(2):228-37.

32. Hosseinzadeh P, Javanbakht MH, Mostafavi SA, Djalali M, Derakhshanian H, Hajianfar H, et al. Brewer's Yeast Improves Glycemic Indices in Type 2 Diabetes Mellitus. Int J Prev Med. 2013;4(10):1131-8.

33. Nakamuro YK, Omaye ST. Metabolic diseases and proand prebiotics: Mechanistic insights. Nutr Metab(Lond). 2012;9(1): 60.

34. Gibson GR, Roberfroid MB. Dietary modulation of the human colonic microbiota: introducing the concept of prebiotics. J Nutr. 1995;125(6):1401-12.

35. Slavin J. Fiber and prebiotics: mechanisms and health benefits. Nutrients. 2013;5(4):1417-35.

36. Mirmiran P, Bahadoran Z, Azizi F. Functional foodsbased diet as a novel dietary approach for management of type 2 diabetes and its complications: A review. World
J Diabetes. 2014;5(3):267-81.

37. Moreno-Indias I, Cardona F, Tinahones FJ, QueipoOrtuno MI. Impact of the gut microbiota on the development of obesity and type 2 diabetes mellitus. Front Microbiol. 2014;5:190.

38. Khan S, Jena G. The role of butyrate, a histone deacetylase inhibitor in diabetes mellitus: experimental evidence for therapeutic intervention. Epigenomics. 2015;7(4):669-80.

39. Everard A, Lazarevic V, Derrien M, Girard M, Muccioli GG, Neyrinck AM, et al. Responses of gut microbiota and glucose and lipid metabolism to prebiotics in genetic obese and diet-induced leptin-resistant mice. Diabetes. 2011;60(11):2775-86.

40. Dehghan P, Gargari BP, Jafar-Abadi MA, Aliasgharzadeh A. Inulin controls inflammation and metabolic endotoxemia in women with type 2 diabetes mellitus: a randomized-controlled clinical trial. Int J Food Sci Nutr. 2014;65(1):117-23.

41. Dehghan P, Pourghassem Gargari B, Asghari Jafarabadi M. Oligofructose-enriched inulin improves some inflammatory markers and metabolic endotoxemia in women with type 2 diabetes mellitus: a randomized controlled clinical trial. Nutrition. 2014;30(4):418-23.

42. Aliasgharzadeh A, Dehghan P, Gargari BP, AsghariJafarabadi M. Resistant dextrin, as a prebiotic, improves insulin resistance and inflammation in women with type 2 diabetes: a randomised controlled clinical trial. Br J Nutr. 2015;113(2):321-30.

43. Gargari BP, Namazi N, Khalili M, Sarmadi B, Jafarabadi MA, Dehghan P. Is there any place for resistant starch, as alimentary prebiotic, for patients with type 2 diabetes? Complement Ther Med. 2015;23(6):810-5.

44. Ziai SA, Larijani B, Akhoondzadeh S, Fakhrzadeh H, Dastpak A, Bandarian F, et al. Psyllium decreased serum glucose and glycosylated hemoglobin significantly in diabetic outpatients. J Ethnopharmacol. 2005;102(2):2027.

45. Dastjerdi MS, Salehioun M, Najafian A, Amini N. A randomized controlled study for evaluation of psyllium effects on kinetics of carbohydrate absorption. J Res Med Sci. 2007;12(3):125-30.

46. Feinglos MN, Gibb RD, Ramsey DL, Surwit RS, McRorie JW. Psyllium improves glycemic control in patients with type-2 diabetes mellitus. Bioactive Carbohydrates and Dietary Fibre. 2013;1:156-61.

47. Asemi Z, Khorrami-Rad A, Alizadeh SA, Shakeri H, Esmaillzadeh A. Effects of synbiotic food consumption on metabolic status of diabetic patients: a double-blind randomized cross-over controlled clinical trial. Clin Nutr. 2014;33(2):198-203. 
48. Shakeri H, Hadaegh H, Abedi F, Tajabadi-Ebrahimi M, Mazroii N, Ghandi Y, et al. Consumption of synbiotic bread decreases triacylglycerol and VLDL levels while increasing HDL levels in serum from patients with type2 diabetes. Lipids. 2014;49(7):695-701.

49. Akram Kooshki A, Tofighiyan T, Rakhshani MH. Effects of Synbiotics on inflammatory markers in patients with type 2 diabetes mellitus. Glob J Health Sci. 2015;7(7 Spec
No):1-5.

50. BahmaniF, Tajadadi-Ebrahimi M, KolahdoozF, Mazouchi M, Hadaegh H, Jamal AS, et al. The consumption of synbiotic bread containing Lactobacillus sporogenes and inulin affects nitric oxide and malondialdehyde in patients with type 2 diabetes mellitus: Randomized, double-blind, placebo-controlled trial. J Am Coll Nutr. 2016;35(6):506-13. 